https://journal.uwgm.ac.id/index.php/abdimasmahakam

E-ISSN: 2549-5755

Januari 2020, Vol. 4 No. 01

Received: September 2019

Accepted: Desember2019

Published: Januari 2020

Article DOI: http://dx.doi.org/ 10.24903/jam.v4i1.770

\title{
Optimalisasi Peran Kader Posyandu dalam Upaya Deteksi Dini Tumbuh Kembang Balita di Wilayah Beji Sidoarum Godean Sleman
}

\author{
Hanifa Andisetyana Putri \\ Universitas 'Aisyiyah Yogyakarta \\ hanifaaputri.90@gmail.com \\ Luluk Khusnul Dwihestie \\ Universitas 'Aisyiyah Yogyakarta \\ lulu.khusnul64@yahoo.com
}

\begin{abstract}
Abstrak
Tujuan pengabdian masyarakat ini yaitu agar kader posyandu balita dapat berperan aktif dan optimal dalam melakukan deteksi dini tumbuh kembang balita dengan KPSP. Metode pelaksanaan kegiatan yaitu menjelaskan solusi yang ditawarkan berdasarkan permasalahan mitra dengan melakukan rekruitmen, pelatihan, pendampingan, dan pemberian pendidikan kesehatan kepada kader posyandu balita dan mitra mengenai deteksi dini tumbuh kembang balita dengan KPSP. Adanya edukasi dan pemberdayaan kader posyandu di wilayah Beji, Sidoarum, Godean sebagai upaya untuk meningkatkan pengetahuan dan ketrampilan kader dalam deteksi dini tumbuh kembang balita dengan KPSP sehingga diharapkan dapat menghasilkan luaran yang positif. Hasil: kegiatan pelatihan kader posyandu balita berjalan dengan baik dan lancar, evaluasi dan monitoring dilakukan 1 bulan setelah pelatihan dan hasilnya kader dapat melakukan deteksi dini tumbuh kembang balita pada saat kegiatan posyandu berlangsung. Luaran kegiatan berupa tekad yang kuat dan kesadaran kader posyandu balita tentang pentingnya pemantauan tumbuh kembang balita, untuk meminimalkan permasalahan tumbuh kembang balita. Peningkatan pengetahuan dan ketrampilan kader posyandu balita dalam pemeriksaan deteksi dini tumbuh kembang balita, sehingga diharapkan pemeriksaan ini dapat dilaksanakan secara rutin agar peningkatan derajat kesehatan balita dapat tercapai dan meminimalisir angka kejadian keterlambatan tumbuh kembang balita.
\end{abstract}

Kata Kunci: pelatihan kader; tumbuh kembang balita; KPSP.

\section{Pendahuluan}

Posyandu adalah salah satu upaya pemberdayaan masyarakat agar ikut serta berperan aktif di bidang kesehatan dalam meningkatkan derajat kesehatan secara optimal. Posyandu merupakan bentuk Upaya Kesehatan Bersumber Daya Masyarakat (UKBM) yang dikelola dan diselenggarakan dari, oleh, untuk dan bersama masyarakat dalam peningkatan kesehatan. Untuk mengurangi angka kematian ibu dan bayi, tidak dapat dilakukan sendiri oleh Pemerintah dan tenaga kesehatan terkait, namun perlu melibatkan masyarakat setempat. 
Pelayanan kesehatan yang mudah dijangkau oleh masyarakat di tingkat pertama yaitu Puskesmas. Program puskesmas yang dipantau secara rutin khususnya untuk kesehatan balita ialah posyandu balita. Pengadaan posyandu balita ini merekrut kader kesehatan dari masyarakat setempat, yang berperan membantu tenaga kesehatan dalam memantau dan mencapai derajat kesehatan balita secara optimal. Sehingga jika posyandu diselenggarakan secara rutin tiap bulan dan baik kualitas pelayanannya, maka upaya pemenuhan kebutuhan dasar balita akan terjaga (Kemenkes RI, 2011).

Posyandu balita merupakan langkah yang strategis dalam peningkatan derajat kesehatan masyarakat khususnya bayi balita. Standarnya pelayanan posyandu untuk bayi dan anak balita harus dilaksanakan dalam situasi yang menyenangkan dan merangsang kreativitas balita. Ruang pelayanan yang memadai, memungkinkan anak balita untuk bermain dengan teman sebayanya, sambil menunggu proses penimbangan dan pengukuran tinggi badan, sehingga orangtua hanya mengawasi. Berbagai macam permainan disediakan sesuai dengan usia balita. Pelayanan kesehatan yang dilaksanakan di posyandu yaitu penimbangan berat badan, penentuan status gizi dan pertumbuhan, edukasi dan konseling kesehatan, pemeriksaan kesehatan oleh tenaga kesehatan Puskesmas setempat, imunisasi dan deteksi dini tumbuh kembang. Sehingga jika ditemukan kecurigaan terhadap tumbuh kembang balita, maka segera dirujuk ke Puskesmas (Kemenkes RI, 2011).

Berdasarkan hasil analisis situasi di wilayah Beji, Sidoarum Godean Sleman merupakan daerah pedesaan di pinggiran kota, dimana masyarakat di wilayah tersebut masih kurang kesadaran dalam kesehatan diri dan keluarga. Sehingga permasalahan kesehatan di daerah tersebut masih cukup kompleks, mulai dari bayi balita, remaja, pasangan usia subur hingga lansia. Berdasarkan hasil wawancara pada 3 kader posyandu balita yang aktif, menyatakan bahwa masyarakat masih jarang untuk mengantarkan anak balitanya ke posyandu, hal ini dikarenakan kurangnya informasi tentang pentingnya kegiatan posyandu. Masyarakat beranggapan bahwa posyandu hanya sekedar melakukan penimbangan bayi balita yang dapat dilakukan di lain waktu.

Permasalahan mitra sesuai dengan program pemerintah bahwa posyandu dapat memonitoring tumbuh kembang balita dan menemukan sedini mungkin apabila ada hambatan/ kelainan pada bayi balita. Diharapkan kader selain trampil memantau pertumbuhan balita dengan melakukan penimbangan berat badan dan pengukuran tinggi badan, sebaiknya kader juga dapat melakukan pemantauan perkembangan balita yaitu deteksi dini tumbuh kembang. Pengabdian masyarakat ini bertujuan untuk melakukan pelatihan kepada kader posyandu balita agar dapat melakukan deteksi dini secara rutin pada balita di wilayahnya. Menurut Depkes RI (2010) deteksi dini tumbuh kembang anak adalah kegiatan atau pemeriksaan untuk menemukan secara dini adanya penyimpangan tumbuh kembang balita dan anak prasekolah.

Deteksi dini dan stimulasi pertumbuhan dan perkembangan anak merupakan upaya mengetahui sedini mungkin gangguan perkembangan pada anak. Kementrian Kesehatan Republik Indonesia telah menyediakan sarana atau alat yaitu Kuesioner Pra Skrining Perkembangan (KPSP) untuk mendeteksi dini pertumbuhan dan perkembangan anak secara sederhana dan mudah dilakukan oleh keluarga, kader, ataupun tenaga kesehatan (Artha, Sutomo \& Gamayanti, 2014).

Pelaksanaan deteksi dini dapat dilakukan oleh siapapun yang telah terampil dan mampu melaksanakan, seperti tenaga profesional (dokter, psikolog, perawat, dan tenaga kesehatan). 


\section{(A) ABDIMAS}

https://journal.uwgm.ac.id/index.php/abdimasmahakam

E-ISSN: 2549-5755

Januari 2020, Vol. 4 No. 01

Selain tenaga kesehatan, masyarakat yang direkrut sebagai kader kesehatan bahkan orangtua atau anggota keluarga dekat juga dapat diajarkan bagaimana cara melakukan deteksi dini tumbuh kembang pada anak. Pemeriksaan tumbuh kembang ini dapat dilakukan di tempat pelayanan kesehatan, posyandu, sekolah, atau lingkungan rumah tangga (Susilaningrum, Nursalam \& Utami, 2013).

Permasalahan perkembangan anak yang kurang optimal, cenderung meningkat. Hal ini dilatarbelakangi keadaan psikososial yang tidak baik, seperti adanya KDRT, sosial ekonomi rendah, pola asuh orangtua yang tidak tepat, serta meningkatnya kasus kekerasan dan pelecehan seksual pada anak. Di Indonesia sekitar 16\% anak usia bawah lima tahun (balita) mengalami gangguan perkembangan saraf dan otak, serta gangguan perkembangan motorik. Selain itu, balita yang mengalami gangguan pendengaran, sehingga mengalami keterlambatan dalam kemampuan bicara, yang berdampak pada kurang optimalnya kecerdasan anak (Depkes RI, 2010). Mayoritas anak dengan penyimpangan tumbuh kembang, tidak terdeteksi saat usia prasekolah karena tidak menunjukkan gejala yang jelas apabila tidak dilakukan pemeriksaan dengan instrument standar. Sehingga skrinning perkembangan anak penting untuk dilaksanakan secara rutin (Artha, Sutomo, \& Gamayanti, 2014).

Ranah perkembangan anak terdiri atas aspek motorik kasar, motorik halus, bahasa/ bicara, dan personal sosial/ kemandirian. Kasus keterlambatan tumbuh kembang anak secara umum terjadi sekitar 5-10\%. Namun, untuk data penyimpangan perkembangan tumbuh kembang anak secara khusus belum dapat dipastikan (Endyarni, 2013).

Masyarakat beranggapan bahwa hal terpenting dalam pertumbuhan dan perkembangan anak hanya sebatas pertumbuhan yang meliputi berat badan dan tinggi badan. Orangtua tidak peduli terhadap perkembangan motorik anak (Artha, Sutomo \& Gamayanti, 2014). Seringkali ditemukan bahwa orangtua tidak menyadari ketika anaknya mengalami keterlambatan perkembangan, seperti saat usia 18 bulan namun anak belum dapat berjalan secara mandiri, orangtua masih sabar menunggu, tanpa membawa anak untuk melakukan pemeriksaan tumbuh kembang. Apalagi untuk kasus keterlambatan kemampuan bicara, orangtua seringkali memaklumi. Memang perkembangan setiap anak berbeda, masing-masing anak mempunyai keunikan tersendiri. Namun, perlu diperhatikan bahwa rutin melakukan pemeriksaan tumbuh kembang, dapat memantau sejauh mana perkembangan anak tersebut, apakah masih dalam batas normal, atau memang sudah dalam kategori terlambat. Untuk itu, orangtua perlu memperhatikan adanya keterlambatan atau penyimpangan, serta tanda bahaya (red flag) pada perkembangan anak (IDAI, 2013).

Pemantauan dan deteksi dini tumbuh kembang anak balita merupakan bagian dari tugas para kader posyandu di wilayah kerjanya masing-masing. Kader kesehatan mempunyai potensi yang sangat besar karena kader sangat dekat (dari sisi geografis dan sosial) dengan masyarakat di wilayahnya. Tugas kader menjadi sangat penting dan kompleks dikarenakan permasalahan tumbuh kembang pada anak tidak hanya fokus pada fisik saja, namun juga meliputi sosial dan mental anak (Sianturi, Tambunan \& Ningsih 2013).

Ellyda, dkk (2018) menyebutkan bahwa minimnya pelatihan dan pembinaan untuk meningkatkan ketrampilan yang memadai bagi kader menyebabkan kurangnya pemahaman kader terhadap tugas dan perannya, lemahnya informasi serta koordinasi antara petugas dan kader dalam pelaksanaan kegiatan posyandu, harus menjadi perhatian yang perlu diperbaiki. Pemeriksaan tumbuh kembang balita hanya dilakukan 3 bulan sekali oleh tenaga kesehatan Puskesmas saat kunjungan, bahkan hanya 1 kader posyandu yang sudah mengikuti pelatihan 


\section{(A) ABDIMAS \\ https://journal.uwgm.ac.id/index.php/abdimasmahakam}

E-ISSN: 2549-5755

Januari 2020, Vol. 4 No. 01

Deteksi Tumbuh Kembang Balita (DTKB). Keterbatasan sumber daya ini menjadi kendala pelaksanaan DTKB secara rutin. Selain itu, Hayati (2015) menambahkan bahwa selama ini pelatihan dan pembinaan kader dilakukan oleh Puskesmas setempat dengan demikian fokus pelatihan lebih menenkankan pada bidang kesehatan. Harapannya kegiatan ini dapat dikembangkan, sehingga kader tidak hanya fokus di bidan kesehatan, namun juga sosial, ekonomi, pendidikan, dan psikologi.

\section{Metode}

Metode pelaksanaan kegiatan menjelaskan solusi yang ditawarkan untuk mengatasi permasalahan yang dilakukan adalah rekruitmen, pelatihan, pendampingan dan pemberian pendidikan kesehatan untuk kader posyandu balita dan mitra. Langkah-langkah yang dilakukan adalah bekerjasama dengan Ibu RT, RW, dan dukuh setempat serta bidan desa untuk mengadakan pertemuan dengan kader posyandu balita untuk melihat gambaran konkret, melakukan pendampingan secara langsung dengan ibu-ibu kader posyandu balita, rekruitmen kader posyandu balita yang aktif dan bersedia mengikuti pelatihan deteksi tumbuh kembang balita dengan KPSP. Minimal kader yang diikutkan pelatihan ada 2 kader setiap RT. Selanjutnya mengadakan pelatihan kader posyandu balita mengenai deteksi dini tumbuh kembang balita dengan KPSP, meliputi penyuluhan, simulasi, pendampingan, monitoring dan evaluasi. Selain itu, mengoptimalkan kader posyandu balita untuk memberikan informasi kepada warga sekitar agar mengunjungi posyandu secara rutin setiap bulan untuk memantau pertumbuhan dan perkembangan balita, mengoptimalkan kader posyandu balita untuk melakukan kunjungan ke rumah apabila terdeteksi ada keterlambatan pertumbuhan dan perkembangan, mengadakan penyuluhan secara menyeluruh berkaitan dengan tumbuh kembang balita dan pentingnya program posyandu balita sebagai penutup.

\section{Hasil dan Pembahasan}

Hasil dan pembahasan kegiatan pengabdian masyarakat ini dilaksanakannya rapat koordinasi dengan Kepala Dukuh dan perwakilan kader posyandu balita. Rapat diadakan sebanyak 2 kali yaitu pada tanggal 5 dan 11 Maret 2017 membicarakan tentang persiapan pelatihan kepada kader posyandu balita, sosialiasi dan rencana rekruitmen kader posyandu balita yang aktif. Selanjutnya, rekruitmen ibu kader posyandu balita, pada tanggal 12 Maret 2017 dengan jumlah peserta 20 kader posyandu yang aktif dan bersedia mengikuti pelatihan deteksi dini tumbuh kembang dengan KPSP. Terakhir, pelatihan kader posyandu balita mengenai deteksi dini tumbuh kembang balita dengan KPSP dilaksanakan selama 2 hari yaitu pada tanggal 14 dan 15 Maret 2017 di rumah Bapak Dukuh Tinom Godean. Jumlah kader yang mengikuti sebanyak 20 orang. Setelah diberikan penyuluhan, maka dilanjutkan dengan pelatihan praktik langsung pada balita mengenai penggunaan KPSP untuk deteksi tumbuh kembang anak. 


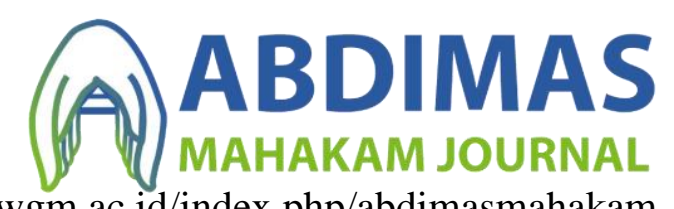

https://journal.uwgm.ac.id/index.php/abdimasmahakam

E-ISSN: 2549-5755

Januari 2020, Vol. 4 No. 01
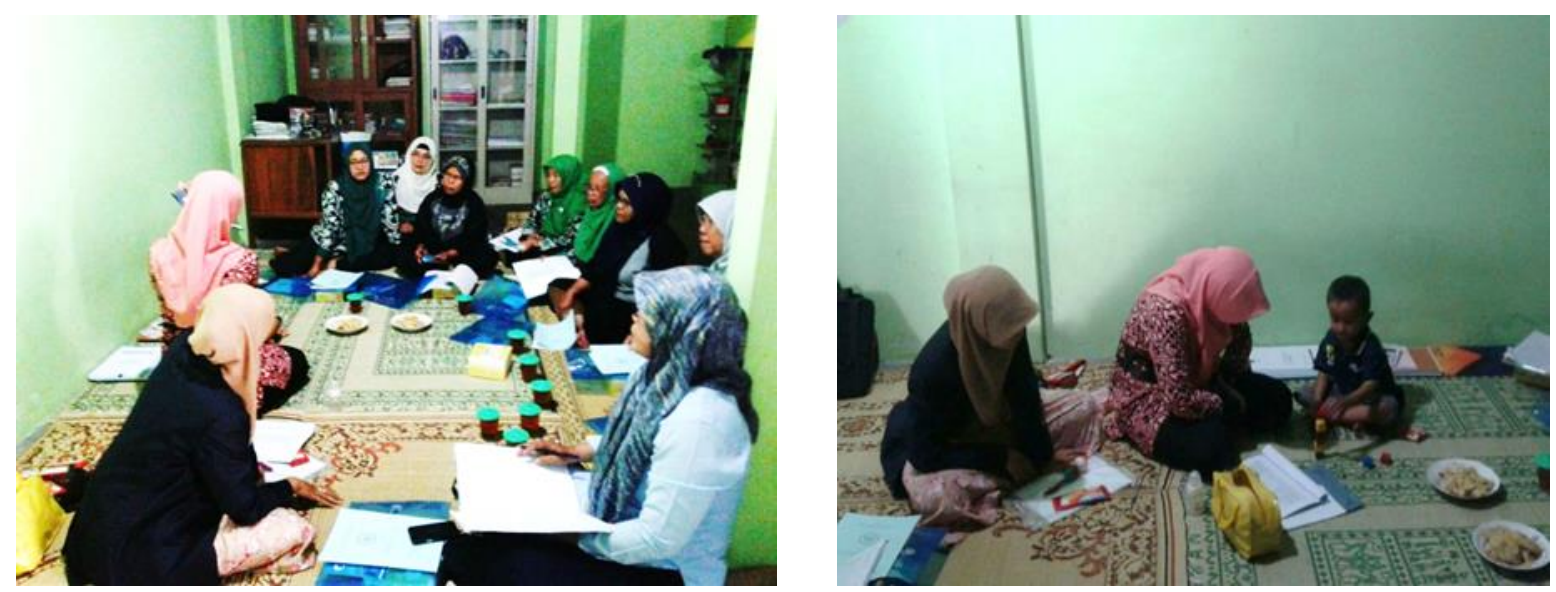

Gambar 1. Pelatihan Deteksi Dini Tumbang

Gambar 2. Simulasi pada balita

Deteksi Tumbuh Kembang Balita (DTKB). Keterbatasan sumber daya ini menjadi kendala pelaksanaan DTKB secara rutin. Selain itu, Hayati (2015) menambahkan bahwa selama ini pelatihan dan pembinaan kader dilakukan oleh Puskesmas setempat dengan demikian fokus pelatihan lebih menenkankan pada bidang kesehatan. Harapannya kegiatan ini dapat dikembangkan, sehingga kader tidak hanya fokus di bidan kesehatan, namun juga sosial, ekonomi, pendidikan, dan psikologi.

Tahapan kegiatan pelatihan tersebut dilakukan dengan penyuluhan mengenai deteksi dini dan pemantauan tumbuh kembang balita pada kader, tokoh masyarakat dan ibu-ibu yang mempunyai balita,dilaksanakan pada tanggal 18 Maret 2017. Selanjutnya, kegiatan monitoring dan peresmian kader posyandu balita dilaksanakan pada tanggal 19 Maret 2017 dipimpin oleh ibu Dukuh Tinom. Sebanyak 20 kader dinyatakan aktif dan trampil dalam deteksi dini tumbuh kembang dengan KPSP. Terakhir, evaluasi dilakukan dengan pemantauan/follow up terkait kemampuan kader posyandu balita dalam menggunakan KPSP pada salah 1 balita pada tanggal 11 April 2017.

Pelaksanaan pelatihan tentang deteksi dini tumbuh kembang balita menggunakan KPSP memberikan pengaruh positif terhadap peningkatan pengetahuan dan kemampuan kader posyandu balita dalam mempraktikkan penggunaan KPSP. Hal ini sesuai dengan teori Notoatmodjo (2010) bahwa seseorang dapat melakukan praktik dengan baik melewati beberapa tingkatan. Tingkatan pertama yaitu persepsi, seseorang mulai mengenal dan memilih berbagai objek sehubungan dengan tindakan yang akan diambil. Kedua, respon terpimpin yaitu seseorang dapat melakukan sesuatu sesuai dengan urutan yang benar dan sesuai contoh yang diberikan saat pelatihan. Ketiga, mekanisme yaitu apabila seseorang telah dapat melakukan sesuatu dengan benar secara otomatis dan menjadi kebiasaan. Dalam hal ini kader posyandu balita sudah dapat menggunakan KPSP tanpa panduan. Keempat, adopsi yaitu suatu praktik yang sudah berkembang dengan baik, artinya tindakan itu sudah dimodifikasi tanpa mengurangi kebenaran tindakan tersebut. Kader posyandu balita sudah dapat menggunakan KPSP sebagai alat untuk mendeteksi dini tumbuh kembang balita secara mandiri.

Salah satu cara untuk mengetahui sejauh mana kefektifan pelatihan ini adalah dengan evaluasi. Kader diberi kesempatan untuk mempraktikkan secara langsung kepada balita untuk mengetahui perkembangan anak tersebut. Modul yang diberikan saat pelatihan digunakan 


\section{(A) ABDIMAS}

https://journal.uwgm.ac.id/index.php/abdimasmahakam

E-ISSN: 2549-5755

Januari 2020, Vol. 4 No. 01

sebagai panduan dalam melakukan deteksi tumbuh kembang, dan kader posyandu balita dapat mempraktikkan setiap langkah-langkah dengan benar. Hal ini menunjukkan bahwa dengan adanya pelatihan meningkatkan pengetahuan dan ketrampilan kader dalam memantau tumbuh kembang balita serta dapat mengetahui rencana tindak lanjut apabila terjadi keterlambatan tumbuh kembang balita.

\section{Simpulan dan rekomendasi}

Berdasarkan hasil monitoring dan evaluasi pelaksanaan pengabdian masyarakat yang berjudul pelatihan kader posyandu balita dalam upaya deteksi dini tumbuh kembang balita dengan KPSP terwujud beberapa target dan luaran diantaranya : terwujudnya kader posyandu balita yang mampu dan mandiri dalam melakukan deteksi dini tumbuh kembang balita dengan KPSP, terwujudnya kader yang mampu memberikan informasi kepada warganya agar mengunjungi posyandu untuk memantau pertumbuhan dan perkembangan balita, terwujudnya kemampuan kader posyandu sayang balita dan anak untuk melakukan kunjungan rumah apabila terdeteksi ada keterlambatan pertumbuhan dan perkembangan, dan terlaksananya penyuluhan secara menyeluruh berkaitan dengan tumbuh kembang balita dan pentingnya program posyandu sebagai penutup. 
https://journal.uwgm.ac.id/index.php/abdimasmahakam

E-ISSN: 2549-5755

Januari 2020, Vol. 4 No. 01

\section{Daftar Pustaka}

Artha, Sutomo \& Gamayanti. (2014). Kesepakatan Hasil antara Kuesioner Pra Skrining Perkembangan, Parent's Evaluation of Development Status, dan Tes Denver-II untuk Skrining Perkembangan Anak Balita dalam http://saripediatri.idai.or.id/pdfile/16-48.pdf

Depkes RI. (2010). Pedoman Pelaksanaan Stimulasi, Deteksi dan Intervensi Dini Tumbuh Kembang (SDIDTK) Anak, DepKes RI, Jakarta dalam http:// www.depkes.go.id/donwload.php

Ellyda, dkk. (2018). Pelatihan Deteksi Tumbuh Kembang Anak Pada Kader Posyandu Ponowaren, Gamping, Sleman. Jurnal Pengabdian dan Pemberdayaan Masyarakat. Vol. 2 No. 2 September 2018. diakses dalam http://jurnalnasional.ump.ac.id/index.php/JPPM/article/view/2632/2196

Endyarni, B. (2013). Mengenal Keterlambatan Perkembangan Umum Pada Anak dalam http://www.idai.or.id/seputar-kesehatan-anak/mengenal-keterlambatanperkembangan-umum-pada-anak.

Hayati, dk. (2015) Pelatihan Kader Posyandu Dalam Deteksi Perkembangan Aanak Usia Dini. Jurnal Pendidikan Anak. Vol. 4 No. 2 (2015) diakses dalam https://journal.uny.ac.id/index.php/jpa/article/view/12359/8929

Kemenkes RI bekerja sama dengan Kelompok Kerja Operasional (POKJANAL POSYANDU). (2011). Pedoman Umum Pengelolaan Posyandu. Jakarta: Kementerian Kesehatan RI.

Notoatmodjo, (2010). Promosi Kesehatan dan Ilmu Perilaku, Jakarta: Rineka Cipta.

Sianturi, Tambunan, Ningsih. (2013). Peningkatan Kemampuan Kader Kesehatan Dalam Melakukan Deteksi Tumbuh Kembang Balita Melalui Pelatihan dalam http:// www. ejurnal.poltekkesjakarta.ac.id.

Susilaningrum, Nursalam, Utami. (2013). Asuhan Keperawatan Bayi dan Anak Edisi 2, Jakarta: Salemba Medika. 